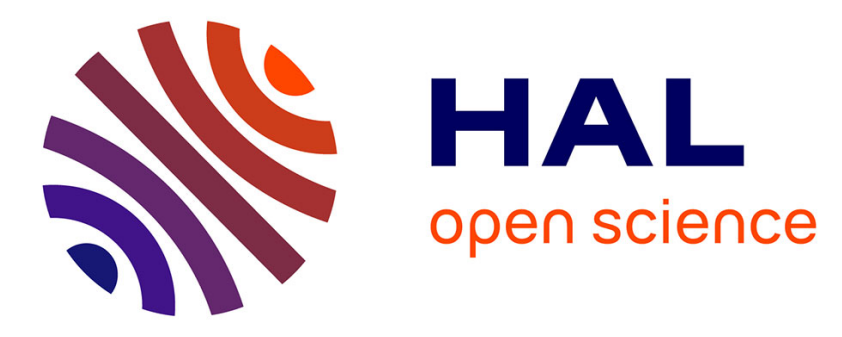

\title{
Genetic polymorphisms of NQO1, CYP1A1 and TPMT and susceptibility to acute lymphoblastic leukemia in a Tunisian population.
}

Slah Ouerhani, Nouha Cherif, Ikbel Bahri, Ines Safra, Samia Menif, Salem Abbes

\section{To cite this version:}

Slah Ouerhani, Nouha Cherif, Ikbel Bahri, Ines Safra, Samia Menif, et al.. Genetic polymorphisms of NQO1, CYP1A1 and TPMT and susceptibility to acute lymphoblastic leukemia in a Tunisian population.. Molecular Biology Reports, 2012, epub ahead of print. 10.1007/s11033-012-2174-y . pasteur-00750943

\section{HAL Id: pasteur-00750943 \\ https://hal-riip.archives-ouvertes.fr/pasteur-00750943}

Submitted on 12 Nov 2012

HAL is a multi-disciplinary open access archive for the deposit and dissemination of scientific research documents, whether they are published or not. The documents may come from teaching and research institutions in France or abroad, or from public or private research centers.
L'archive ouverte pluridisciplinaire HAL, est destinée au dépôt et à la diffusion de documents scientifiques de niveau recherche, publiés ou non, émanant des établissements d'enseignement et de recherche français ou étrangers, des laboratoires publics ou privés. 


\title{
Genetic polymorphisms of $N Q O 1, C Y P 1 A 1$ and TPMT and susceptibility to acute lymphoblastic leukemia in a Tunisian population
}

\author{
Slah Ouerhani • Nouha Cherif • Ikbel Bahri • \\ Ines Safra · Samia Menif · Salem Abbes
}

Received: 5 July 2012/ Accepted: 8 October 2012

(C) Springer Science+Business Media Dordrecht 2012

\begin{abstract}
Acute lymphoblastic leukemia (ALL) is the major pediatric cancer in developed countries. The etiology of ALL remains poorly understood, with few established environmental risk factors. These risks were influenced by co-inheritance of multiple low-risk genetic polymorphisms such as variants within cytochrome P450A1 (CYP1A1), NADPH: quinone oxidoreductase $(\mathrm{NQO1})$ and Thiopurine methyltransferase (TPMT) genes. In this work, we conduct a case-control study to assess the impact of $C Y P 1 A 1 * 2 A$ (CYP1A1 T6235C); NQO1*2 (NQO1 C609T); TPMT*2 (TPMT G238C) and TPMT A719G polymorphisms on the risk of developing ALL. The frequencies of $T P M T * 2$, TPMT A719G, NQO1*2 and CYPIAI*2 variants were examined in 100 patients with ALL and 106 healthy controls by allele specific PCR and/or PCR-RFLP methods using blood samples. We have found that NQO1 609CT genotype was overrepresented in patients and was associated with an aggravating effect compared to the reference group with NQO1 609CC genotype $(p=0.028$, $\mathrm{OR}=1.41 ; \mathrm{CI} 95 \%$ : 1.04-1.93). However, TPMT*2, TPMT $719^{*} G$ and $C Y P 1 A 1 * 2$ variants did not appear to influence ALL susceptibility $(p>0.05)$. Moreover we have not found a significant correlation between the studied variants and $\mathrm{Bcr}-\mathrm{Abl}$ transcript. In conclusion we retain that leukemogenesis of ALL is associated with carcinogens metabolism and consequently related to environmental exposures.
\end{abstract}

Nouha Cherif and Ikbel Bahri contributed equally to this study.

S. Ouerhani $(\bowtie) \cdot$ N. Cherif · I. Bahri · I. Safra · S. Menif . S. Abbes

Laboratory of Molecular and Cellular Haematology, Pasteur Institute of Tunis, University of Tunis El Manar, Tunis, Tunisia e-mail: slah_mekni@yahoo.fr
Keywords Leukemia - Tunisia - TPMT · NQO1 · CYP1A1

\section{Introduction}

Acute lymphoblastic leukemia (ALL) is the major pediatric cancer in developed countries [1]. This pathology is characterized by many chromosomal abnormalities that produce aberrant gene fusions or inappropriate expression of oncogenes. Among them rearrangements of the mixedlineage leukemia $(M L L)$ gene localized in 11q23 are common chromosomal abnormalities associated with acute leukemia, especially infant leukemia and secondary leukemia following treatment with DNA topoisomerase II inhibitors. Translocation $(9 ; 22)$ associated with the Bcr$\mathrm{Abl}$ transcript is the most frequent genetic aberration in adult ALL and is found in 20-30\% of patients overall [2]. The etiology of ALL remains poorly understood, with few established environmental risk factors [3-5]. It is, however, likely that the risk of ALL from environmental exposure is influenced by co-inheritance of multiple low-risk variants. For example previous case-control studies have shown that variants within cytochrome p4501A1 (CYP1A1), NQO1 or TPMT were associated with increased risk of ALL [6-10].

CYP1A1 enzyme belongs to the cytochrome P450 family and is a phase I detoxification enzyme involved in the bioactivation of several chemical carcinogens, including cytotoxic drugs. CYP1A1 transfers electrons onto toxicants to create highly reactive intermediates which are usually coupled to glutathione or other groups, producing water-soluble compounds, but can also interact with DNA, resulting in the formation of DNA adducts [11]. The expression of genes from the CYP1 family increases in lymphoblastic and myeloblastic cell lines and plays a role 
in the detoxification of environmental factors. Therefore, CYP1A1 enzyme might be responsible for carcinogenesis in haematopoietic cells. This protein is encoded by a polymorphic gene localized in chromosome 15q24.1. There have been many single nucleotide polymorphisms (SNPs) identified in the CYPIAl gene. In particular, two common polymorphisms, the $\mathrm{T} 6235 \mathrm{C}$ change within the $3^{\prime}$ non-coding region of the gene $(C Y P 1 A l * 2 A, \mathrm{rs} 464690)$ and the $\mathrm{A} 4889 \mathrm{G}$ change in the heme-binding domain of exon $7(C Y P 1 A 1 * 2 C)$, have been previously described. The $C Y P 1 A 1 * 2 A$ variant was associated with an increasing enzymatic activity and/or inducibility and was one of the most studied polymorphisms in association with leukemia $[6,7]$.

Other metabolic gene variants that have been investigated as risk factors for ALL include polymorphisms in NADPH:quinone oxidoreductase (NQO1). The encoded enzyme is a 274 -aminoacid flavoprotein that catalyzes the two-electron reduction of quinoid compounds into their reduced form, such as hydroquinones. NQO1 protein protects cells against quinine-induced oxidative stress. Mice lacking the NQO1 protein demonstrated increased sensitivity to benzo(a)pyrene- and 7,12-dimethylbenz(a)anthracene-induced carcinogenesis of the skin [12, 13]. Moreover, this enzyme activates nitrosoaromatic compounds and heterocyclic amines in tobacco smoke, which may work to induce carcinogenesis $[14,15]$. The NQO1 protein is encoded by a polymorphic gene localized in chromosome 16q22.1. There have been more than 93 single nucleotide polymorphisms (SNPs) identified in the NQO1 gene. The most widely studied SNP of $N Q O 1$ is a C to $\mathrm{T}$ change at nucleotide position 609 (rs1800566), also known as $N Q O 1 * 2$ [16]. This results in a proline to serine amino acid change at codon 187 that is associated with a loss of enzyme activity due to instability of the protein product. The $N Q O 1 * 2$ is associated with an increased risk of tobacco-related cancers and ALL [8, 9, 17, 18]. Moreover other polymorphisms were detected in NQO1 gene and were associated with the modification of the enzyme activity like the $N Q O 1 * 3$. However the frequency of $N Q O 1 * 3$ in different ethnic populations is generally low [19].

The TPMT enzyme catalyses the $S$-methylation of azathioprine, 6-thioguanine and 6-mercaptopurine (6-MP). These three drugs are used for the treatment of patients with several disorders such as ALL, rheumatoid arthritis, systemic lupus erythematosus or other autoimmune/ inflammatory diseases as well as of those undergoing organ transplants [20-22]. This enzyme is encoded by the TPMT gene which localized in chromosome 6p22.3. Twenty-four TPMT genetic polymorphisms have been identified, and they are associated with decreased levels of TPMT activity and/or thiopurine drug-induced toxicity [23, 24]. Four mutant alleles, $T P M T * 2, \quad T P M T * 3 A, T P M T * 3 B$ and $T P M T * 3 C$, account for the majority of variant alleles in all human populations studied to date [25]. The distribution of these alleles differs significantly among ethnic populations [26-28].

Considering the role in detoxification played by these enzymes, the existence of common polymorphisms $(N Q O 1 * 2, C Y P 1 A 1 * 2 A, T P M T * 2$ and TPMT A719G) and previous report of their association with other cancers, we aimed at determining whether any association between these polymorphisms and susceptibility to ALL. We have also investigated the correlation between these polymorphisms and the Bcr-Abl transcript.

\section{Materials and methods}

\section{Subjects}

Our analysis included 106 controls and 100 patients with ALL. All patients were recruited at the first diagnosis from the laboratory of molecular and cellular haematology from Pasteur Institute of Tunis, Tunisia. The diagnosis of leukemia subgroups was based on the standard clinico-haematological criteria and molecular analysis. Patients were recruited from different geographic origins, among them $68.00 \%$ were men and the mean age was $23.35 \pm 7.79$ years. The control group consisted of healthy unrelated volunteers without a medical history of cancer. The control group was approximately matched for gender proportion, geographic origin and age range to those in the case group.

\section{DNA and RNA extraction}

Under informed consent, peripheral blood samples were collected into tubes with EDTA. The red cells were lysed and residual cells were homogenised in $1 \mathrm{ml}$ trizol. For patients, total RNA was extracted from peripheral blood cells by using the acid guanidinium thiocyanate and phenol chloroform method. After having taken the aqueous phase with RNA, we carefully remove the interphase which contains DNA. The DNA extraction was done in accordance with the manufacturer's instructions. For controls subjects, genomic DNA was extracted by the phenol/ chloroform protocol. The quality of genomic DNA was controlled by electrophoresis on a $1 \%$ agarose gel stained with ethidium bromide.

Bcr-abl and abl transcripts analysis for ALL patients

$b c r-a b l$ and $a b l$ transcripts was identified as previously reported by Menif et al. [29]. The two transcripts were quantified using a commercially available fusion Quant kit 
(IPSOGEN) developed according to the EAC network protocol. cDNA was amplified by 50 cycles of Q-PCR using the ABI 7700 sequence detection system (Applied Bisystems, Foster City, CA, USA) and taqMAN ${ }^{\circledR}$ Universal PCR Master Mix in accordance with the manufacturer's instructions in a final reaction volume of $25 \mu \mathrm{l}$. The $b c r-a b l$ and $a b l$ probes were dual labeled with FAM and TAMRA; the probe and primer concentrations for $a b l$ mRNA quantification were 200 and $300 \mathrm{nM}$, respectively.

Genotyping of NQO1 C609T, CYP1A1 T6235C, TPMT G238C and TPMT A719G

The amplified fragment size and the primers used for all amplifications were shown in Table 1. For NQO1 and CYP1A1 genes, we screened the NQO1 C609T and CYPIAl T6235C mutations by PCR/RFLP approach. The PCR reactions were performed in a final volume of $25 \mu \mathrm{l}$ containing $100 \mathrm{ng}$ of genomic DNA, $2.5 \mu \mathrm{l}$ of $10 \times$ PCR buffer, $1.25 \mu \mathrm{l}$ of $\mathrm{Mgcl}_{2}$ at $50 \mathrm{mM}, 5 \mathrm{pmol}$ of each primer and $1 \mathrm{U}$ of Taq DNA polymerase (Invitrogen). PCR was carried out as follows: an initial denaturising step $\left(94^{\circ} \mathrm{C}\right.$ for $\left.10 \mathrm{~min}\right)$, was followed by 30 cycles consisting of denaturising $\left(94{ }^{\circ} \mathrm{C}\right.$ for $60 \mathrm{~s}$ ), primer annealing (at $58{ }^{\circ} \mathrm{C}$ for $N Q O 1$ and at $62{ }^{\circ} \mathrm{C}$ for $C Y P 1 A 1$ for $30 \mathrm{~s}$ ) and extension $\left(72^{\circ} \mathrm{C}\right.$ for $\left.60 \mathrm{~s}\right)$. The mixture was then heated at $72{ }^{\circ} \mathrm{C}$ for $10 \mathrm{~min}$. To detect the NQO1 C609T transition, the PCR products were digested at $37{ }^{\circ} \mathrm{C}$ overnight with $10 \mathrm{U}$ of HinfI. The size of obtained fragments after HinfI digestion and the expected genotypes for $N Q O 1$ gene were summarized in Fig. 1. To detect the CYP1A1 T6235C transition, the PCR product was digested at $37{ }^{\circ} \mathrm{C}$ overnight with $5 \mathrm{U}$ of $M S P I$. After MSPI digestion, the wild allele ( $\left.C Y P 1 A 16235^{*} T\right)$ was characterized by the presence of only one band of $343 \mathrm{pb}$, however the mutated allele (CYP1A1 6235*C) was marked by the presence of two band of 209 and $134 \mathrm{pb}$. After PCR/RFLP, the presence of mutated alleles (NQO1 609*T and CYPIA1 6235*C) was confirmed by direct sequencing.

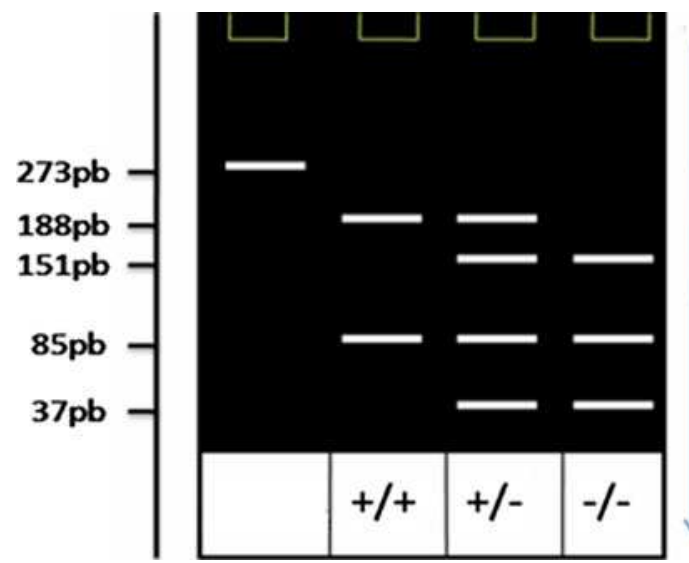

Fig. 1 Sizes of obtained fragments after HinfI digestion and the expected genotypes for $\mathrm{NQO1}$ gene. $+/+$ homozygous wild genotype, \pm heterozygous genotype, $-/-$ homozygous mutated genotype

For TPMT gene the TPMT*2 (G238C) variant was detected by allele specific PCR and the TPMT A719G mutation was investigated by direct sequencing of purified PCR products with the Big Dye Terminator kit V 1.1 (Applied Biosystems).

\section{Statistical analysis}

The Hardy-Weinberg equilibrium test was calculated by the software package Arlequin (version 3.01). Statistical analysis was performed by SPSS 16.0 software.

\section{Results}

All samples were found to be in Hardy-Weinberg equilibrium for CYP1A1, NQO1 and TPMT genotypes (Table 2). The alleles frequencies for $C Y P 1 A 16235 * C, N Q O 1609 * T$, TPMT $238^{*} C$ and TPMT $719^{*} G$ (mutated alleles) in control population were respectively estimated at $0.05,0.22,0.11$ and 0.004. Genotypes and alleles distributions for CYP1A1,

Table 1 Primer sequences, amplified fragment sizes and annealing temperatures

\begin{tabular}{|c|c|c|c|}
\hline Studied polymorphisms & Sequences & Fragment sizes $(\mathrm{pb})$ & Annealing $\mathrm{T}\left({ }^{\circ} \mathrm{C}\right)$ \\
\hline$N Q O 1 * 2(C 609 T)$ & $\begin{array}{l}\text { F: 5'-AGTGGCATTCTGCATTTCTGTG-3' } \\
\text { R: 5'-GATGGACTTGCCCAAGTGATG-3' }\end{array}$ & 273 & 58 \\
\hline$C Y P 1 A 1 * 2 A(T 6235 C)$ & $\begin{array}{l}\text { F: 5'-CAGTGAAGAGGTGTAGCCGCT-3' } \\
\text { R: 5'-TAGGAGTCTTGTCTCATGCCT-3' }\end{array}$ & 343 & 62 \\
\hline$T P M T * 2(G 238 C)$ & $\begin{array}{l}\text { PC: 5'-TAAATAGGAACCATCGGACAC-3' } \\
\text { PW: 5'-GTATGATTTTATGCAGGTTTG-3' } \\
\text { PM: 5'-GTATGATTTTATGCAGGTTTC-3' }\end{array}$ & 256 & 57 \\
\hline TPMT A719G & $\begin{array}{l}\text { F: 5'-GAGACAGAGTTTCACCATCTTGG-3' } \\
\text { R: 5'-CAGGCTTTAGCATAATTTTCAATTCCTC-3' }\end{array}$ & 373 & 62 \\
\hline
\end{tabular}

$F$ forward primer, $R$ reverse primer, $P C$ common primer, $P W$ wild primer, $P M$ mutated primer 
Table 2 Hardy-Weinberg equilibrium test for $N Q O 1 * 2, C Y P 1 A 1 * 2 A$, $T P M T * 2$ and TPMT A719G polymorphisms

\begin{tabular}{|c|c|c|c|c|c|c|}
\hline \multirow[t]{3}{*}{ Variant } & \multicolumn{6}{|l|}{ Group } \\
\hline & \multicolumn{3}{|c|}{ Controls } & \multicolumn{3}{|l|}{ Cases } \\
\hline & $\begin{array}{l}\text { Obs. } \\
\text { Het }\end{array}$ & $\begin{array}{l}\text { Exp. } \\
\text { Het }\end{array}$ & $p$ value & $\begin{array}{l}\text { Obs. } \\
\text { Het }\end{array}$ & $\begin{array}{l}\text { Exp. } \\
\text { Het }\end{array}$ & $p$ value \\
\hline$N Q O 1 * 2$ & 0.301 & 0.351 & 0.16 & 0.450 & 0.433 & 0.81 \\
\hline$C Y P 1 A 1 * 2 A$ & 0.103 & 0.098 & 1.00 & 0.180 & 0.196 & 0.32 \\
\hline$T P M T^{*} 2$ & 0.198 & 0.209 & 0.632 & 0.240 & 0.242 & 1.00 \\
\hline$T P M T * A 719 G$ & 0.009 & 0.009 & 1.000 & 0.01 & 0.01 & 1.00 \\
\hline
\end{tabular}

Obs. Het observed heterozygous genotype, Exp. Het expected heterozygous genotype

NQO1 and TPMT genes in cases and controls were summarized in Table 3.

For the NQO1 C609T genotype, significant differences in genotype frequencies between cases and controls were detected with considering both co-dominant and dominant models (Table 3). For this locus, NQO1 609CT genotype was found to be overrepresented in patients and associated with an aggravating effect compared to reference group harbouring NQO1 609CC genotype $(p=0.028$, $\mathrm{OR}=1.41$; CI $95 \%: 1.04-1.93)$. We have also shown that the $N Q O 1609 * T$ allele increases significantly the risk of ALL in the Tunisian population $(p=0.049)$. For the CYP1A1 T6235C polymorphism, we have shown that the CYP1A1 $6235^{*} C$ allele was overrepresented in ALL patients (Table 3). However we have not found a significant statistical difference (corrected $p$ value is 0.06 ).

With respect to TPMT variation we have found that the frequencies of $T P M T * 2$ and $T P M T 719^{*} G$ alleles did not differ significantly between cases and controls. These results were obtained for the dominant, co-dominant and recessive models (Table 3 ). These results suggest that $T P M T * 2$ and TPMT $719^{*} G$ variants were not implicated in genetic susceptibility to ALL for the Tunisian population.

Finally we have used the multinomial logistic regression to investigate relation between genetic polymorphisms and bcr-abl status. Information about Bcr-Abl transcript status was available for only 77 patients. Of them Bcr-Abl was detected on only 17 patients. These patients were distributed according to transcript type as $11.7 \%$ (9/77) with b3a2, $6.5 \%(5 / 77)$ with e1e2 and $3.9 \%$ (3/77) with b2a2 variant. The comparison of CYP1A1, NQO1 and TPMT genotypes distribution between patients stratified according to the Bcr-Abl transcript status does not show any significant statistical difference (Table 4).

\section{Discussion}

Acute lymphoblastic leukemia is the major pediatric cancer in developed countries. The risk of developing ALL may be influenced by polymorphisms of xenobiotic metabolizing enzymes. Thus, in this population-based, case-control study, we investigated the association between xenobioticmetabolizing gene polymorphisms and susceptibility to ALL in a Tunisian population.

The frequency of $N Q O 1 * 2$ variant in our control population was estimated at 0.22 . This value is in the range of reported frequencies for African populations. Indeed Kelsey et al. [30] estimated the frequency of $N Q O 1 * 2$ in a African-American group at 0.22 . Moreover a recent study focusing the analysis of $N Q O 1$ polymorphisms and susceptibility to atopy and airway hyperresponsiveness has reported that the frequency of $N Q O 1 * 2$ variant in African children was estimated at 0.15 [31]. However these frequencies are slightly higher than those usually found in Caucasian populations [32] and lower to which founded for the Chinese population [33]. When we compare the frequencies of $N Q O 1 * 2$ variant between patients and controls we have found that $N Q O 1609 C T$ genotype was associated with a 1.41-fold increased risk of developing ALL. This result confirms the studies of Smith et al. [9] and Krajinovic et al. [18]. Moreover a recent a meta-analysis of Vijayakrishnan and Houlston [34] has revealed a significant association between $N Q O 1 * 2$ variant and ALL $(\mathrm{OR}=1.24,95 \% \mathrm{CI}: 1.02-1.50)$. We explain the positive asociation between $N Q O 1 * 2$ variant and ALL by reducing detoxifying power for toxic quinone and free radicals and/ or by decreasing stability of p53. Indeed, it is well known that the wild NQO1 enzyme protects the cell against the oxidative stress and toxic quinone $[35,36]$ and stabilizes the $\mathrm{p} 53$ protein $[37,38]$. In opposition to our results other authors have found a positive association between the NQO1 CC (homozygous wild genotype) and the increased risk of ALL [39]. Authors explain this association by the role of wild NQO1 enzyme in activating carcinogens aside from detoxification. This hypothesis is supported by the review of Ross [36] who has postulated that some endogenous metabolites can be transformed by NQO1 to yield more active products that can produce reactive oxygen or alkylating species, thus attacking nucleophilic sites within essential biomolecules such as DNA. These apparent discrepancies might reflect differences in the chemical carcinogens involved in leukaemogenesis in different countries. In the other hand the correlation between $N Q O 1 * 2$ variant and Bcr-Abl transcript does not show any significant statistical difference which confirms the study of Kracht et al. [40]. In this context others studies have examined the $N Q O 1 * 2$ distribution according to MLL rearrangement status and have produced conflicting result. While Lanciotti et al. [8] indicate that only the infantile ALL patients without MLL rearrangements had a significantly higher frequency of $N Q O 1$ genotypes associated with low/null activity enzyme. Wiemels et al. [41] have 
Table 3 Genotypes distribution for NQO1, CYP1A1 and TPMT in cases and controls from Tunisia

\begin{tabular}{|c|c|c|c|c|c|}
\hline Polymorphism & Genotypes & Controls $(n=106)$ & Cases $(n=100)$ & $p$ value (Yates correction) & OR $(95 \% \mathrm{CI})$ \\
\hline \multirow[t]{13}{*}{$N Q O 1 * 2(C 609 T)$} & \multicolumn{5}{|c|}{ Co-dominant model } \\
\hline & $\mathrm{CC}$ & 66 & 46 & - & $1^{*}$ \\
\hline & $\mathrm{CT}$ & 32 & 45 & 0.028 & $1.41(1.04-1.93)$ \\
\hline & TT & 8 & 9 & 0.510 & - \\
\hline & \multicolumn{5}{|c|}{ Dominant model } \\
\hline & $\mathrm{CC}$ & 66 & 46 & - & $1^{*}$ \\
\hline & $\mathrm{CT}+\mathrm{TT}$ & 40 & 54 & 0.028 & $1.38(1.05-1.83)$ \\
\hline & \multicolumn{5}{|c|}{ Recessive model } \\
\hline & $\mathrm{TT}$ & 8 & 9 & - & $1^{*}$ \\
\hline & $\mathrm{CT}+\mathrm{CC}$ & 98 & 91 & 0.900 & - \\
\hline & \multicolumn{5}{|l|}{ Alleles } \\
\hline & $\mathrm{C}$ (wild) & 164 & 137 & - & $1 *$ \\
\hline & $\mathrm{T}$ (mutated) & 48 & 63 & 0.049 & $1.26(1.00-1.60)$ \\
\hline \multirow[t]{13}{*}{ CYPIAl $* 2 A(T 6235 C)$} & \multicolumn{5}{|c|}{ Co-dominant model } \\
\hline & TT & 95 & 80 & - & $1^{*}$ \\
\hline & $\mathrm{TC}$ & 11 & 18 & 0.152 & - \\
\hline & $\mathrm{CC}$ & 0 & 2 & 0.413 & - \\
\hline & \multicolumn{5}{|c|}{ Dominant model } \\
\hline & $\mathrm{TT}$ & 95 & 80 & - & $1 *$ \\
\hline & $\mathrm{TC}+\mathrm{CC}$ & 11 & 20 & 0.08 & - \\
\hline & \multicolumn{5}{|c|}{ Recessive model } \\
\hline & $\mathrm{CC}$ & 0 & 2 & - & $1^{*}$ \\
\hline & $\mathrm{TC}+\mathrm{TT}$ & 106 & 98 & 0.452 & - \\
\hline & \multicolumn{5}{|l|}{ Alleles } \\
\hline & $\mathrm{T}$ (wild) & 191 & 178 & - & $1^{*}$ \\
\hline & C (mutated) & 11 & 22 & 0.065 & - \\
\hline \multirow[t]{13}{*}{$T P M T * 2(\mathrm{G} 238 \mathrm{C})$} & \multicolumn{5}{|c|}{ Co-dominant model } \\
\hline & GG & 83 & 74 & - & $1^{*}$ \\
\hline & GC & 21 & 24 & 0.572 & - \\
\hline & $\mathrm{CC}$ & 2 & 2 & 1.00 & - \\
\hline & \multicolumn{5}{|c|}{ Dominant model } \\
\hline & GG & 83 & 74 & - & $1^{*}$ \\
\hline & $\mathrm{GC}+\mathrm{CC}$ & 23 & 26 & 0.575 & - \\
\hline & \multicolumn{5}{|c|}{ Recessive model } \\
\hline & $\mathrm{CC}$ & 2 & 2 & - & $1^{*}$ \\
\hline & $\mathrm{GC}+\mathrm{GG}$ & 104 & 98 & 1.00 & - \\
\hline & \multicolumn{5}{|l|}{ Alleles } \\
\hline & $\mathrm{G}$ (wild) & 187 & 172 & - & $1^{*}$ \\
\hline & C (mutated) & 25 & 28 & 0.602 & - \\
\hline \multirow[t]{13}{*}{ ТРMT A719G } & \multicolumn{5}{|c|}{ Co-dominant model } \\
\hline & AA & 105 & 99 & - & $1^{*}$ \\
\hline & AG & 1 & 1 & 1.00 & - \\
\hline & GG & 0 & 0 & - & - \\
\hline & \multicolumn{5}{|c|}{ Dominant model } \\
\hline & $\mathrm{AA}$ & 105 & 99 & - & $1^{*}$ \\
\hline & $\mathrm{AG}+\mathrm{GG}$ & 1 & 1 & 1.00 & - \\
\hline & \multicolumn{5}{|c|}{ Recessive model } \\
\hline & GG & 0 & 0 & - & $1^{*}$ \\
\hline & $\mathrm{AG}+\mathrm{AA}$ & 106 & 100 & - & - \\
\hline & \multicolumn{5}{|l|}{ Alleles } \\
\hline & A (wild) & 211 & 199 & - & $1^{*}$ \\
\hline & $\mathrm{G}$ (mutated) & 1 & 1 & 1.00 & - \\
\hline
\end{tabular}

$1 *$ reference group, $O R$ odds ratio, $C I$ confidence interval 
Table 4 Logistic regression effect of NQO1, CYP1A1 and TPMT2 polymorphisms on Bcr-Abl status

\begin{tabular}{|c|c|c|c|c|c|}
\hline \multirow[t]{2}{*}{ Transcrit $^{\mathrm{a}}$} & \multirow[t]{2}{*}{ df } & \multirow[t]{2}{*}{ Sig. } & \multirow[t]{2}{*}{$\operatorname{Exp}(\mathrm{B})$} & \multicolumn{2}{|c|}{$95 \%$ confidence interval for $\operatorname{Exp}(B)$} \\
\hline & & & & Lower bound & Upper bound \\
\hline$[\mathrm{NQO} 1 * 2=\mathrm{C} / \mathrm{C}]$ & 1 & 0.615 & 0.654 & 0.125 & 3.423 \\
\hline$[N Q O 1 * 2=C / T]$ & 1 & 0.367 & 0.445 & 0.077 & 2.583 \\
\hline$[N Q O 1 * 2=T / T]$ & 0 & - & - & - & - \\
\hline$[C Y P 1 A 1 * 2 A=C / C]$ & 1 & 0.993 & 3.109 & 0.000 & - \\
\hline$[C Y P 1 A 1 * 2 A=T / C]$ & 1 & 0.421 & 1.700 & 0.467 & 6.185 \\
\hline$[C Y P 1 A 1 * 2 A=T / T]$ & 0 & - & - & - & - \\
\hline$[T P M T * 2=C / C]$ & 1 & 0.995 & 3.316 & 0.000 & $-{ }^{b}$ \\
\hline$[T P M T * 2=G / C]$ & 1 & 0.409 & & 0.135 & 2.257 \\
\hline$[T P M T * 2=G / G]$ & 0 & - & - & - & - \\
\hline$[T P M T A 719 G=A / A]$ & 1 & - & 3,597 & 3.597 & 35.970 \\
\hline$[$ TPMT $A 719 G=A / G]$ & 0 & - & - & - & - \\
\hline
\end{tabular}

This reduced model was obtained after adjustment to sex and age

Logistic regression: number of observation $=77, \chi^{2}=88.409, p=0.000$

$D f$ degree of freedom, Sig. $p$ value, $\operatorname{Exp}(B)$ expected odds ratio

a The reference category is patients without Bcr-Abl

b This parameter is set to zero because it is redundant

Table 5 Summary of some studies reporting the association between NQO1 and ALL

\begin{tabular}{|c|c|c|c|c|c|c|c|}
\hline \multirow{2}{*}{$\begin{array}{l}\text { First author } \\
\text { [reference] }\end{array}$} & \multirow[t]{2}{*}{ Population/country } & \multirow{2}{*}{$\begin{array}{l}\text { Cases } \\
(n)\end{array}$} & \multirow{2}{*}{$\begin{array}{l}\text { Controls } \\
(n)\end{array}$} & \multicolumn{2}{|l|}{ Variant } & \multirow{2}{*}{$\begin{array}{l}\text { Tumours } \\
\text { types }\end{array}$} & \multirow{2}{*}{$\begin{array}{l}\text { Odds ratio } \\
(95 \% \mathrm{CI})\end{array}$} \\
\hline & & & & $\% N Q O 1 * 2^{\mathrm{a}}$ & $\% N Q O 1 * 2^{\mathrm{b}}$ & & \\
\hline Present study & Tunisian & 106 & 100 & 31.50 & 22.64 & ALL & $1.26(1.0-1.60)$ \\
\hline Rimando et al. [39] & Filipino & 60 & 60 & 0.20 & 0.39 & ALL & $4.82(2.1-10.6)^{\mathrm{d}}$ \\
\hline Lanciotti et al. [8] & Italian & 18 & 147 & $72^{c}$ & $38^{\mathrm{c}}$ & $\mathrm{ALL}^{\mathrm{e}}$ & $4.22(1.43-12.49$ \\
\hline Kracht et al. [40] & $\begin{array}{l}\text { Austria, Germany, Czechoslovakia } \\
\text { (Caucasian) }\end{array}$ & 138 & 190 & 0.36 & 0.35 & $A L L^{f}$ & NS \\
\hline Krajinovic et al. [18] & French-Canadian & 174 & 323 & 22.4 & 17.8 & ALL & $1.3(1.0-1.8)$ \\
\hline Smith et al. [9] & United Kingdom & 67 & 108 & $43.48^{\mathrm{c}}$ & $32.40^{\mathrm{c}}$ & ALL & $1.93(0.96-3.87)$ \\
\hline Wiemels et al. [41] & United Kingdom & 36 & 100 & 0.32 & 0.17 & ALL/AML ${ }^{g}$ & $2.54(1.08-5.96)$ \\
\hline
\end{tabular}

$A L L$ acute lymphoblastic leukemia

${ }^{\text {a }}$ Variant frequencies in cases

b Varaint frequencies in controls

${ }^{c}$ Percentage of low/null activity CT + TT genotype

d Positive association with NQO1 homozygous wild genotype, NS no statistical significant association

e MLL negative

${ }^{f}$ ALL carrying distinct fusion genes

gLL positive

found that low $N Q O 1$ activity genotypes (heterozygous CT or homozygous TT) were associated with ALL containing the $M L L$ gene rearrangements. Table 5 summarizes our data and some studies on $N Q O 1 * 2$ and the risk of ALL.

The frequency of $C Y P 1 A 1 * 2 A$ variant in our control population was estimated at 0.05 . This frequency is lower to which reported by other studies $[6,7]$. The comparison of patients and controls according to CYPIAI*2 variant does not show a statistical significant difference (corrected $p$ value $=0.06$ ). Our observation is compatible with the findings of Liu et al. [42]. In contradiction Krajinovic et al. [43] and Clavel et al. [44] suggest that individuals harbouring the $C Y P 1 A 1 * 2$ variant may be at an increased risk for ALL. Indeed the $C Y P 1 A 1 * 2$ variant is associated with 
elevated enzymatic activity supporting the hypothesis of linking the risk of ALL with the inducibility of the xenobiotic metabolizing enzyme CYP1A1. Consequently, carriers of variant alleles are expected to present greater risk when exposed to carcinogens such as polycyclic aromatic hydrocarbons. With considering the TPMT variations we have found that the frequencies of $T P M T * 2$ variant and "low" TPMT genotypes in the healthy Tunisian population were higher to which reported for the Caucasian populations [45-47]. Moreover high frequency of TPMT "low" alleles was observed for ALL patients. For these patients low TPMT activity can cause toxic concentration of thioguanine nucleotides in hematopoietic cells after treatment with thiopurine drugs. The greatest risk of hematopoietic toxicity is associated with homozygous TPMT variants. However, patients known to be TPMT-deficient can be successfully treated with reduced dosages of thiopurines [48]. Although the high frequency of TPMT "low" alleles in Tunisian population in both cases and controls we have found that these variants were not implicated in genetic susceptibility to ALL. This result was in contradiction with a previously reported study of Samochatova et al. [10]. In this study we explain the absence of positive association between $C Y P 1 A 1 * 2$ variant, TPMT low allele and ALL by differences in the chemical carcinogens involved in leukemogenesis in different countries.

Finally, although some of the results presented here are novel and presented for the first time for the Tunisian population, this study has some limitations. The primary limitation of our study is the small sample size and, as a consequence, low statistical power to detect associations. The second limitation of this study is the absence of epidemiologic information such as tobacco status and other environmental risk factors. Besides that, in the future, enlargement of sample sizes in the Tunisian population (which is already ongoing) will be essential to assess the role that non genetic baseline factors together with the genetic factors play as predictors of differential susceptibility to the malignancy.

\section{Conclusion}

In this study we find statistical evidence that $N Q O 1 * 2$ variant was associated with an increased risk of ALL in a Tunisian population. This finding suggests that leukemogenesis of ALL is associated with carcinogen metabolism and consequently related to environmental exposures.

\section{Acknowledgments None.}

Conflict of interest All authors would like to declare that they have no conflict of interest.

\section{References}

1. Stiller CA, Parkin DM (1996) Geographic and ethnic variations in the incidence of childhood cancer. Br Med Bull 52(4):682-703

2. Radich JP (2001) Philadelphia chromosome-positive acute lymphocytic leukemia. Hematol Oncol Clin North Am 15:21-36

3. Raaschou-Nielsen O, Reynolds P (2006) Air pollution and childhood cancer: a review of the epidemiological literature. Int $\mathbf{J}$ Cancer 118(12):2920-2929

4. Belson M, Kingsley B, Holmes A (2007) Risk factors for acute leukemia in children: a review. Environ Health Perspect 115: 138-145

5. Linabery AM, Ross JA (2008) Trends in childhood cancer incidence in the U.S. (1992-2004). Cancer 112(2):416-432

6. Balta G, Yuksek N, Ozyurek E et al (2003) Characterization of MTHFR, GSTM1, GSTT1, GSTP1, and CYP1A1 genotypes in childhood acute leukemia. Am J Hematol 73(3):154-160

7. Canalle R, Burim RV, Tone LG et al (2004) Genetic polymorphisms and susceptibility to childhood acute lymphoblastic leukemia. Environ Mol Mutagen 43(2):100-109

8. Lanciotti M, Dufour C, Corral L et al (2005) Genetic polymorphism of $\mathrm{NAD}(\mathrm{P}) \mathrm{H}$ :quinone oxidoreductase is associated with an increased risk of infant acute lymphoblastic leukemia without MLL gene rearrangements. Leukemia 19(2):214-216

9. Smith MT, Wang Y, Kane E et al (2001) Low NAD(P)H:quinone oxidoreductase 1 activity is associated with increased risk of acute leukemia in adults. Blood 97:1422-1426

10. Samochatova EV, Chupova NV, Rudneva A (2009) TPMT genetic variations in populations of the Russian Federation. Pediatr Blood Cancer 52(2):203-208

11. Ingelman-Sundberg M (2001) Genetic susceptibility to adverse effects of drugs and environmental toxicants. The role of the CYP family of enzymes. Mutat Res 482:11-19

12. Long DJ II, Waikel RL, Wang XJ et al (2000) NAD(P)H:quinine oxidoreductase 1 deficiency increases susceptibility to benzo(a)pyrene-induced mouse skin carcinogenesis. Cancer Res 60: 5913-5915

13. Long DJ II, Waikel RL, Wang XJ et al (2001) NAD(P)H:quinine oxidoreductase 1 deficiency and increased susceptibility to 7,12dimethylbenz[a]-anthracene-induced carcinogenesis in mouse skin. J Natl Cancer Inst 93:1166-1170

14. De Flora S, Bennicelli C, D'Agostini F et al (1994) Cytosolic activation of aromatic and heterocyclic amines. Inhibition by dicoumarol and enhancement in viral hepatitis B. Environ Health Perspect 102(Suppl 6):69-74

15. Knox ChenS, Lewis AD et al (1995) Catalytic properties of $\mathrm{NAD}(\mathrm{P}) \mathrm{H}$ :quinone acceptor oxidoreductase: study involving mouse, human, and mouse-rat chimeric enzymes. Mol Pharmacol 47:934-936

16. Iida A, Sekine A, Saito S et al (2001) Catalog of 320 single nucleotide polymorphisms (SNPs) in 20 quinone oxidoreductase and sulfotransferase genes. J Hum Genet 46:225-240

17. Hamajima N, Matsuo K, Iwata $\mathrm{H}$ et al (2002) NAD(P)H: quinone oxidoreductase 1 (NQO1) C609T polymorphism and the risk of eight cancers for Japanese. Int J Clin Oncol 7:103-108

18. Krajinovic M, Sinnett H, Richer C et al (2002) Role of NQO1, MPO and CYP2E1 genetic polymorphisms in the susceptibility to childhood acute lymphoblastic leukemia. Int J Cancer 97(2):230-236

19. Gaedigk A, Tyndale RF, Jurima-Romet $M$ et al (1998) NAD(P)H: quinone oxidoreductase: polymorphisms and allele frequencies in Caucasian, Chinese and Canadian Native Indian and Inuit populations. Pharmacogenetics 8(4):305-313

20. Schutz E, Gummert J, Mohr F et al (1993) Azathioprine-induced myelosuppression in thiopurine methyltransferase deficient heart transplant recipient. Lancet 341:436 
21. Kerstens PJ, Stolk JN, de Abreu R et al (1995) Azathioprinerelated bone marrow toxicity and low activities of purine enzymes in patients with rheumatoid arthritis. Arthritis Rheum 38:142-145

22. McLeod HL, Relling MV, Liu Q et al (1995) Polymorphic thiopurine methyltransferase in erythrocytes is indicative of activity in leukemic blasts from children with acute lymphoblastic leukemia. Blood 85:1897-1902

23. Salavaggione OE, Wang L, Wiepert M et al (2005) Thiopurine S-methyltransferase pharmacogenetics: variant allele functional and comparative genomics. Pharmacogenet Genomics 15:801-815

24. Schaeffeler E, Zanger UM, Eichelbaum M et al (2008) Highly multiplexed genotyping of thiopurine s-methyltransferase variants using MALD-TOF mass spectrometry: reliable genotyping in different ethnic groups. Clin Chem 54:1637-1647

25. McLeod HL, Krynetski EY, Relling MV et al (2000) Genetic polymorphism of thiopurine methyltransferase and its clinical relevance for childhood acute lymphoblastic leukemia. Leukemia $14: 567-572$

26. Otterness D, Szumlanski C, Lennard L et al (1997) Human thiopurine methyltransferase pharmacogenetics: gene sequence polymorphisms. Clin Pharmacol Ther 62:60-73

27. Hon YY, Fessing MY, Pui CH et al (1999) Polymorphism of the thiopurine S-methyltransferase gene in African-Americans. Hum Mol Genet 8:371-376

28. Collie-Duguid ESR, Pritchard SC, Powrie RH et al (1999) The frequency and distribution of thiopurine methyltransferase alleles in Caucasian and Asian populations. Pharmacogenetics 9:37-42

29. Menif S, Zarrouki S, Jeddi R et al (2009) Quantitative detection of bcr-abl transcripts in chronic myeloid leukemia. Pathol Biol 57(5):388-391

30. Kelsey KT, Ross D, Traver RD et al (1997) Ethnic variation in the prevalence of a common $\mathrm{NAD}(\mathrm{P}) \mathrm{H}$ quinone oxidoreductase polymorphism and its implications for anti-cancer chemotherapy. Br J Cancer 76(7):852-854

31. Reddy P, Naidoo RN, Robins TG et al (2010) GSTM1, GSTP1, and NQO1 polymorphisms and susceptibility to atopy and airway hyperresponsiveness among South African schoolchildren. Lung 188(5):409-414

32. Guha N, Chang JS, Chokkalingam AP et al (2008) NQO1 polymorphisms and de novo childhood leukemia: a HuGE review and meta-analysis. Am J Epidemiol 168(11):1221-1320

33. Ross D, Kepa JK, Winski SL et al (2000) NAD(P)H:quinone oxidoreductase 1 (NQO1): chemoprotection, bioactivation, gene regulation and genetic polymorphisms. Chem Biol Interact 129(1-2):77-97

34. Vijayakrishnan J, Houlston RS (2010) Candidate gene association studies and risk of childhood acute lymphoblastic leukemia: a systematic review and meta-analysis. Haematologica 95(8): $1405-1414$

35. Ernester L (1998) DT-diaphorase: its structure, function, regulation, and role in antioxidant defence and cancer chemotherapy.
In: Yagi K (ed) Pathophysiology of lipid peroxides and related free radicals. S Karger, Basel, pp 149-168

36. Ross D (1997) Quinone reductases. In: Guengerich FP (ed) Comprehensive toxicology, vol 3. Pergamon Press, New York, pp 179-197

37. Asher G, Lotem J, Kama R et al (2002) NQO1 stabilizes p53 through a distinct pathway. Proc Natl Acad Sci USA 99:3099-3104

38. Anwar A, Dehn D, Siegel D et al (2003) Interaction of human $\mathrm{NAD}(\mathrm{P}) \mathrm{H}$ :quinone oxidoreductase 1 (NQO1) with the tumor suppressor protein p53 in cells and cell-free systems. J Biol Chem 278:10368-10373

39. Rimando MG, Chua MN, Yuson ED et al (2008) Prevalence of GSTT1, GSTM1 and NQO1 $(609 \mathrm{C}>\mathrm{T})$ in Filipino children with ALL (acute lymphoblastic leukaemia). Biosci Rep 28(3):117-124

40. Kracht T, Schrappe M, Strehl S et al (2004) NQO1 C609T polymorphism in distinct entities of pediatric hematologic neoplasms. Haematologica 89(12):1492-1497

41. Wiemels JL, Pagnamenta A, Taylor GM et al (1999) A lack of a functional $\mathrm{NAD}(\mathrm{P}) \mathrm{H}$ : quinone oxidoreductase allele is selectively associated with pediatric leukemias that have MLL fusions. United Kingdom Childhood Cancer Study Investigators. Cancer Res 59:4095-4099

42. Liu QX, Chen HC, Liu XF et al (2005) Study on the relationship between polymorphisms of CYP1A1, GSTM1, GSTT1 genes and the susceptibility to acute leukemia in the general population of Hunan province. Zhonghua Liu Xing Bing Xue Za Zh 26(12):975-979

43. Krajinovic M, Labuda D, Richer C et al (1999) Susceptibility to childhood acute lymphoblastic leukemia: influence of CYP1A1, CYP2D6, GSTM1, and GSTT1 genetic polymorphisms. Blood 93(5):1496-1501

44. Clavel J, Bellec S, Rebouissou S et al (2005) Childhood leukaemia, polymorphisms of metabolism enzyme genes, and interactions with maternal tobacco, coffee and alcohol consumption during pregnancy. Eur J Cancer Prev 14(6):531-540

45. Ameyaw MM, Collie-Duguid ES, Powrie RH et al (1999) Thiopurine methyltransferase alleles in British and Ghanaian populations. Hum Mol Genet 8(2):367-370

46. Spire-Vayron de la Moureyre C, Debuysere H, Mastain B et al (1998) Genotypic and phenotypic analysis of the polymorphic thiopurine S-methyltransferase gene (TPMT) in a European population. Br J Pharmacol 125:879-887

47. Yates CR, Krynetski EY, Fessing MY et al (1997) Molecular diagnosis of thiopurine S-methyltransferase deficiency: genetic basis for azathioprine and mercaptopurine intolerance. Ann Intern Med 126:608-614

48. Relling MV, Hancock ML, Rivera GK et al (1999) Mercaptopurine therapy intolerance and heterozygosity at the thiopurine S-methyltransferase gene locus. J Natl Cancer Inst 91:2001-2008 